\title{
RAYMOND CARVER: LANGUAGE AND SILENCE CARVING THE HOPELESS AMERICANS
}

\author{
RAYMOND CARVER: LINGUAGEM E SILÊNCIO \\ ESCULPINDO OS AMERICANOS DESESPERADOS
}

\section{Carlos Böes de Oliveira}

Recebido em: 06 de maio de 2017

Aprovado em: 28 de junho de 2017

Sistema de Avaliação: Double Blind Review

RPR | a. 14 | v. 2 | p. 5-15 | jul./dez. 2017

\begin{abstract}
Raymond Carver was a great North American short writer in the 1970's and 1980's. His writings have singular characteristics, such as: a minimalist style; desperate characters in constant financial a familiar struggle; the characters' inability to articulate any kind of concealing communication; and the presence of silence as a place of resistance. This study intends to analyze the use of language and the lack of it in the literature of Raymond Carver. The main goal of this paper is to verify how the recurrent use of silence helps as a mechanism of social resistance, and how this artifice is fundamental in maintaining the world the character inhabit from falling apart. Another aspect analyzed in this paper is how the lack of communication from the masculine characters affect their own masculinities, making them fragile. To support this study the discourse analysis from Michel Pecheux, and its theoretical presuppositions about ideology, language and the subject are applied. To analyze the use of silence in the literature of Raymond Carver, Eni Orlandi is brought to usage, as much as scholars that study Carver and theoreticians that discuss lacanian psychanalysis. It is expected to conclude that the use of silence, as a means of communication, by the author's characters is a vulnerable strategy that this people find to avoid their social sphere from collapsing.
\end{abstract}

Keywords: Raymond Carver. Discursive formation. Silence.

\section{RESUMO}

Raymond Carver foi um grande contista norte-americano nas décadas de 1970 e 1980. Seus escritos têm características muito marcantes, entre elas: um estilo minimalista; personagens desesperados e em constante dificuldade financeira e familiar; a incapacidade de suas personagens articularem uma comunicação conciliadora; e a presença do silêncio como local de resistência. Este estudo pretende analisar o uso da linguagem e da falta desta na literatura de Raymond Carver. O desígnio central deste trabalho é verificar como o uso recorrente do silêncio serve de mecanismo de resistência social, e como este subterfúgio utilizado pelas personagens é fundamental para evitar que o universo social dos sujeitos desmorone. Outro aspecto analisado neste artigo é como a falta de comunicação por parte das personagens masculinas afeta suas próprias masculinidades, deixando-as frágeis. Para embasar este estudo, a análise do discurso da escola de Michel Pecheux, e seus pressupostos teóricos sobre ideologia, língua e sujeito são trazidos à tona. Para analisar o uso do silêncio na literatura de Carver, Eni Orlandi é utilizada, bem como estudiosos da literatura de Raymond Carver e acadêmicos da psicanálise lacaniana. Espera-se concluir que o uso do silêncio, como forma de comunicação, pelas personagens do autor seja uma estratégia vulnerável que estes sujeitos encontram de manter o seu universo em pé.

Palavras-chave: Raymond Carver. Formação discursiva. Silêncio.

\footnotetext{
1 Doutorando com bolsa PROSUP/CAPES na University of New Mexico (Albuquerque/Estados Unidos). E-mail: caio.boes@gmail.com.
} 


\section{RAYMOND CARVER AND PECHEUX}

The writing of Raymond Carver is the perfect object of study for French Discourse Analysis, since, the works of the author are focused on the unique use of language and its elliptical characteristic; the characters of Carver's fictional world are representative of a repressed social class desiring to move upwards in the social pyramid. In addition, Carver uses silence as a main factor of communication and subversion of social status. We have to remind ourselves that the French Discourse Analysis by Pecheux understands language as a necessary mediation between man and his social and natural reality. This mediation is called discourse, and discourse is responsible for the feeling of permanency and continuity as much as displacement and transformation of man and his social existence. In Carver's texts, language and communication are almost always factors that characters have problems to deal with, therefore, they use silence quite regularly. Silence, in the stories, usually represents a place of permanency and continuity to the social spheres of characters. Silence, most often, tends to imprison characters in an oppressed discursive formation, while communication, is the place of displacement and social transformation. The discourse analyst is aware that within language, there are things that cannot be said, things that are untranslatable to words. This space of untranslatability creates a mechanism of indetermination which opens doors to ambiguity, and this is a fundamental property of all natural languages. The discourse analyst does not see the untranslatable or ambiguity in a negative panorama, but he sees them as a place of resistance, where they represent a place of difference within the dominant system. It is also an effective way to perceive the subject that produces and/or detects such ambiguity and untranslatability better.

\section{VOICELESS DESPERATION}

An expert reader on Carver recognizes that a constant throughout his fictional creation is the presence of characters that are not happy or satisfied with their social position. Carver created subjects that are representative of a lower, desperate social class. Every little thing in the characters' lives is a component of a desperate existence: the characters' marriages are often destroyed, filled with infidelity, alcoholism and financial hardship; a broken refrigerator and the meat inside being rotten is a symptom of the internal catastrophe these characters are passing through. Carver's characters can certainly be classified as losers in a country that respects and worships ambition and achievement. In a closer analysis, the reader realizes these characters are not defeated, but are in a process of struggling. The America Carver constructs is helpless and desperate, shadowed by the pain and the loss of dreams, but it is certainly not as fragile as it seems. Carver's America is a place of survivors. As Kirk Nesset comments in regards to the characters that people Carver's fictional universe:

They talk, however unsuccessfully; they have sex or avoid it. They employ both their bodies and tongues in efforts to find themselves again, struggling to reassemble the bits and pieces of their tattered identities - and they continue struggling, even as their bodies get them into trouble, and as their tongues, taking them forever in circles, fall silent (1991, p. 295).

The materiality of the ideology(ies) in the world of Carver is manifested both in silence and in the hard language the narrators and the subject/characters use. Carver creates a style where the blank spaces are as important as the spaces filled with words. Silence works as a factor of threat and menace that echoes through the stories and the reader has the feeling that he is aware of something the characters 
are not. It is this sense that the reader is missing something that helps give him a feeling of menace. In an essay titled On writing, Raymond Carver said:

I like it when there is a feeling of threat or a sense of menace in short stories. I think a little menace is fine to have in a story. For one thing, it's good for the circulation. There has to be tension, a sense that something is imminent, that certain things are in relentless motion, or else, most often, there simply won't be a story. What creates tension in a piece of fiction is partly the way the concrete words are linked together to make up the visible action of the story. But it's also the things that are left out, that are implied, the landscape just under the smooth (but sometimes broken and unsettled) surface of things (1983, p. 26).

The reader is induced to fill in the blank spaces of the sentences with meanings that would symbolize a pessimistic and oppressive world. The meanings, in a way, seem to be always there, evident to the eye, although, it is the position of the reader that enables such a reading.

The meanings are always "managed", they are not loose. In face of any type of fact, of any symbolic object, we are induced to interpret, as if there is an injunction towards interpretation. When we speak, we interpret. But at the same time, meanings seem to always be there. ${ }^{2}$ (ORLANDI, 2000, p. 10).

Here I will depict some aspects present in Carver's early stories, basically, focusing on his first two collections of stories: Will you please be quiet, please? (1976) and What we talk about when we talk about love (1981). These two collections represent the minimalist period of the author, where ellipse is a key element in the stories. I start my analysis focusing on the transgression the characters face, when they try to transit to different discursive formations, using silence as transportation. In a second moment, I establish Carver's construction and deconstruction of masculinities in his stories through discourse.

\section{TRYING TO INHABIT DIFFERENT DISCURSIVE FORMATIONS}

A great example to illustrate the figure of the loser in Raymond Carver can be found in the short story called Neighbors, from Carver's first collection of stories Will you please be quiet, please? (1976). The story is evidently short, with approximately eight pages, and it portrays a third person narrator, which is a technique that can create a feeling that repels the reader from the characters, by removing their personal voices. There are sporadic dialogues in the story, and those that are present, are definitely shaped by the unsaid. The story depicts the life of two different couples who live in the same building, the Millers and the Stones. These two couples represent two distinct discursive formations. The Millers could be portrayed as the losers, dissatisfied with the life they lead. They have low self-esteem and are sexually frustrated. The opposite situation can be seen in the imaginary the Millers have of their neighbors, the Stones: "It seemed to the Millers that the Stones lived a fuller and brighter life. The Stones were always going out for dinner, or entertaining at home, or travelling about the country somewhere in connection with Jim's work." (CARVER, 1976, p.9) These two discursive formations enter in conflict when the Stones let the Millers take care of their apartment for the period of ten days while the endure a business travel. They should water the plants and feed the cat. What really starts to happen is that Bill and Arlene Miller start to transit in a different discursive formation. By doing that, the Millers institute a process where they lose their identities. For the Millers, to be in the Stone's apartment is to be a

\footnotetext{
2 Original: “Os sentidos estão sempre 'administrados', não estão soltos. Diante de qualquer fato, de qualquer objeto simbólico somos instados a interpretar, havendo uma injunção a interpretar. Ao falar, interpretamos. Mas, ao mesmo tempo, os sentidos parecem já estar sempre lá”.
} 
completely different person. The following quotation exemplifies the drive that guides the characters into desire, and it reveals a common structure perpetuated in America:

\begin{abstract}
Carver's characters want what everyone else wants. Their desire is borrowed; it is the conventional desire in the consumer-capitalist, nuclear family-oriented culture in which they live. But, because they are American, there is no limit to the range and scale of their desire: they are free to desire what they wish. This freedom is popularly conceived of as the zero degree of individualism, a notion that one is born into a fantasy playground of pure potentiality with the freedom to go anywhere, do anything, have anything, be anyone. Sooner or later comes the realization that the idea of freedom is just that, an idea. For most people, limitation and constraint, personal or social, are life's realities (CORNWELL, 2005, p. 345)
\end{abstract}

This process of moving to a different discursive formation is also highly aphrodisiac. In a different discursive formation which, before this situation, was unreachable, the Milers become sexually aroused, fulfilling their most inner unconscious desires. Right after visiting the Stones' apartment for the first time, Bill returns to his home with a great deal of sexual appetite:

"What kept you?" Arlene said. She sat with her legs turned under her, watching television.

"Nothing. Playing with Kitty," he said, and went over to her and touched her breasts. "Let's go to bed, honey," he said (CARVER, 1976, p. 11).

In this passage we can also find an example of constitutive silence, where someone says (x) because (y) cannot be said. When Arlene asks Bill why it took him so long to come back, he answered that he was "playing with Kitty." But the reader knows he was doing other things. Bill was experimenting himself in a different space. "He headed for the bathroom. He looked at himself in the mirror and then closed his eyes and then looked again." (CARVER, 1976, p. 10) Bill robbed some pills that were inside the medicine chest in the bathroom, and, in the living room, he had two drinks from the bottle of Chivas Regal. What does this represent? One can infer that Bill Miller was already showing an indication that the Stone's apartment could be a place where he might experiment new things, and those new things that were prohibited to him in his discursive formation. After the first visit, the sexual stimulation will be a constant in their lives right after they return from the neighbor's apartment.

On the second day, Bill leaves his job a little earlier than he usual, so he could spend more time in the apartment. When he returns to his own apartment, again, he and Arlene have sex:

"Let's go to bed," he said.

"Now?" She laughed. "What has gotten into you?

"Nothing. Take your dress off." He grabbed for her awkwardly, and she said, "Good God, Bill."

He unfastened his belt.

Later they sent out for Chinese food, and when it arrived they ate hungrily, without speaking, and listened to records (CARVER, 1976, p. 11).

At first, this phenomenon happens to Bill. It is he who is responsible for going to the neighbor's apartment with the excuse of feeding the cat and watering the plants. But the apartment becomes the place of the unconscious, where time passes in an irregular way. The feeling that Bill is losing his identity is taken to extremes, to a point where he tends to believe that he is somebody else, or even the Stones. We have this evidence in the fact that Bill develops the obsession of looking at himself in the mirror when he is in the Stones' apartment. On the first visit he makes at the Stones, the mirror obsession starts: "He headed for the bathroom. He looked at himself in the mirror and then closed his eyes and then looked again" (CARVER, 1976, p. 10). On the following visitations this phenomenon is repeated 
continuously. At another moment of the short story, Bill opens his neighbors' wardrobe, chooses a Hawaiian shirt and Bermudas and looks at himself in the mirror. This might indicate that he feels like a "tourist" in that place, but he decides to change his clothes right after that. So he puts on a blue suit and black dress shoes as if he were imagining himself in the social position of his neighbor. And finally, not recognizing himself in the mirror with these clothes, Bill wears a pair panties and a bra belonging to Harriet Stone. We can infer that because of these acts, Bill does not recognize his identity anymore, and that he is experimenting different identities. These events could be analyzed by lacanian psychoanalysis, in what concerns the mirror stage. The mirror stage represents the entering of the subject in the world of the symbolic. It is when the baby, by seeing his image reflected in the mirror, starts a journey to recognition, separating himself from his mother, that up until then, he believed was a part of himself. This prime identification of the individual with his image is the origin of the rest of his identifications. It is an immediate and "dual" identification, reduced to two terms, the body and its image. Lacan qualifies it as the imaginary, since the individual recognizes himself with a copy of his own body, with an image that is not really him, but that allow him to find recognition. And by doing so, the baby fills the emptiness between the two terms of this relation: the body and the image. We are talking about a relation that is characterized by indistinction, the confusion between oneself and the other, and also by alienation, because the subject does not have any distance in relation to his own image, making him confuse his body with the resembling other.

Arlene also decides to visit the Stones' apartment, after she perceives the changes that are taking place with Bill. The same phenomenon seems to be happening to her. When Bill goes to the neighbor's apartment looking for his wife, the same dialogue they had before is repeated:

"Was I gone long?" she said.

"Well, you were," he said.

"Was I?" she said. "I guess I must have been playing with Kitty."

He studied her, and she looked away, her hand still resting on the doorknob (CARVER, 1976, p. 15).

The same sentence Bill used to silence what in fact really had happened inside the apartment is repeated with Arlene: "I guess I must have been playing with Kitty." That is when Bill "notices white lint clinging to the back of her sweater, and the colors were high in her cheeks. He began kissing her on the neck and hair and she turned and kissed him back" (CARVER, 1976, p. 15). She could have been trying out different clothes, and also, noticing her high colored cheeks, the reader is able to infer that Arlene is sexually aroused. When the couple starts kissing at the door, Bill suggests getting some cigarettes so they could come back, together this time, to their neighbor's apartment and then fulfill their fantasies together. They lock the door of their own apartment, and, holding hands in the hall, between their own apartment and the neighbor's, separated by two different discursive formations, they stop.

They held hands for the short walk across the hall, and when he spoke she could barely hear his voice.

"The key," he said. "Give it to me."

"What?" she said. She gazed at the door.

"The key," he said. "You have the key."

"My God," she said. "I left the key inside."

He tried the knob. It was locked. Then she tried the knob. It would not turn. Her lips were parted, and her breathing was hard, expectant. He opened his arms and she moved into them.

"Don't worry," he said into her ear. "For God's sake, don’t worry." (CARVER, 1976, p. 16). 
It is at this point where the short story comes to an end. The Millers have trespassed their discursive formation when they were in their neighbor's apartment. But now, the door was locked. They did not have the key to open that door. Their desires cannot be satisfied anymore. The hall puts them in a void and in a situation of uncertainty about the future. This is suggested by the type of comfort the husband offers to his wife: "For God's sake, don't worry." The reader notices the silent desperation in this enunciation, creating an almost contradictory sentence. The Millers cannot return to the place of fulfilled desires the apartment represented, and they cannot occupy the discursive formation they were enjoying any longer. That discursive formation has been denied to them. They leaned into the neighbor's door, and "as if against a wind" (CARVER, 1976, p. 16), they resisted together, but now they are repelled from the place, being forced to return to their discursive formation. This short story illustrates well the dilemmas suffered by a discursive formation that represents the oppressed. The world keeps these losers from moving, forcing them to remain in the same static discursive formation.

\section{WHEN THE WHITE MAN IS IN SOCIAL JEOPARDY}

Raymond Carver's characters want more. They are unsatisfied with their lives, their jobs (if they have any), their marriage and kids. These characters want more, but, frequently, they do not know how to obtain "that something else". Still talking about Carver's first collection of short fiction, Will you please be quiet, please? (1976), we can find an emblematic example of dissatisfaction in the short story They're Not Your Husband. The story focuses on a man who is a loser but does not want to recognize himself as one. In his ideological construct, he is a manly, powerful, white male, but that does not match with his real conditions of existence, remembering that, ideology represents the imaginary relation between individuals and their real conditions of existence. The first sentence of the short story opens with: "Earl Ober was between jobs as a salesman" (CARVER, 1976, p. 22). In an American capitalist context in which a man's value is measured by his income, we can infer that Earl Ober has a terrible self-esteem. The first sentence is followed by the information that his wife Doreen worked the night shifts in a coffee shop at the edges of town. That information, revealed in the first three lines of the story is a perfect portrait of the family: down and out losers suffering to make a living. One night, after drinking, Earl decides to go to the coffee shop, because he wanted to see where Doreen worked and also, because he expected to get a free meal on his wife's account. Arriving at the coffee shop, Earl sits at a table, while two men, in "business suits, ties undone... collars open sat down next to him and asked for coffee" (CARVER, 1976, p. 22). These two men represent, exactly what Earl is not, which is: employed workers. The suit also reveals that they are not only "mere" hard workers, but, at least, blue-collar ones. These businessmen represent a dominant discursive formation in the universe of Earl Ober. The two men started talking, and Earl was listening to them.

As Doreen walked away with the coffeepot, one of the men said to the other,

"Look at the ass on that. I don't believe it."

The other man laughed. "I've seen better," he said.

"That's what I mean," the first man said. "But some jokers like their quim fat."

"Not me," the other man said.

"Not me, neither," the first man said. "That's what I was saying."

She came back with the pot and poured coffee for him and for the two men. Then she picked up a dish and turned to get some ice cream. She reached down in the container and with the dipper began to scoop up the ice cream. The white skirt yanked against her hips and crawled up her legs. What showed was girdle, and it was pink, thighs that were rumpled and grey and a little hairy, and veins that spread in a berserk display. 
The two men sitting beside Earl exchanged looks. One of them raised his eyebrows. The other man grinned and kept looking at Doreen over his cup as she spooned chocolate syrup over the ice cream. When she began shaking the can of whipped cream, Earl got up, leaving his food, and headed for the door. He heard her call his name, but he kept going (CARVER, 1976, p. 22-23).

Earl Ober is not angered by the cruelty of the men who were treating his wife as an object (an object of desire), in fact, he feels humiliated by that. There is a sentence in the conversation between the businessmen that classifies the woman's partner as a joker: "some jokers like their quim fat." Jokers, in this case, is a synonym for loser, as much as quim, a mispronunciation of queen, also reveals a ridicularization of the woman. The reader has a clear sense of that and the psychological drama of the passage is evident: Earl's self-esteem is embodied in the object of desire, which, in this case is his wife, who had been ridicularized by those two "successful" men. The ridicularization of Doreen by the businessmen, removes all the value Earl attributed to his wife, and consequently, to himself, making him feel useless and oppressed.

The issue of love, or, more accurately, the absence of it is a constant throughout all Carver's work, be it fiction or poetry. Kirk Nesset, an expert on Raymond Carver and professor of the University of California, describes love in the works of Raymond Carver as: "A darkly unknowable and irreversible force, a form of sickness not only complicating but dominating the lives of characters. Characters are alternately bewildered, enraged, suffocated, diminished, isolated and entrapped by love" (1991, p. 293294) After hearing what the men had to say about Doreen, Earl leaves the coffee shop in a hurry, and deals with the problem as many other Carver characters do: having no understanding of it at an emotional level, but taking it into a physical sphere:

He checked on the children and then went to the other bedroom and took off his clothes. He pulled the covers up, closed his eyes, and allowed himself to think. The feeling started in his face and worked down into his stomach and legs. He opened his eyes and rolled his head back and forth on the pillow. Then he turned on his side and fell asleep (CARVER, 1976, p.23).

His actions show that he is not feeling comfortable. The feeling of uneasiness and misplacement Earl feels is transferred to his wife the next morning when he suggests and convinces her that she needs to start a diet. The reader can infer that if Doreen loses weight, Earl would be able to restore his pride and value. He could then be a man again. He could then, restore his position in a "dominant" discursive formation, because we have to remember that gender is a construct, like anything else is, and Earl was completely lost in relation to his identity. The encounter with the businessmen in the coffee shop has brought some traumatic issues to the surface of things. The imaginary formation in which Earl inscribes himself, as a white dominant male is put in jeopardy, not to say the most evident transformation, which is his undefined position in a discursive formation. He believed he was a Man who possessed a beautiful and sexy wife. Although he did not have a job, he had a wife, and others would envy him because of this. When he discovered that men, who were in a higher social position, did not have any sexual interest in his wife, Earl felt lost. He could not identify himself in a subject-position (discursive formation) that had some kind of power, and he certainly did not want to recognize himself as a useless loser, or a joker, as the men in suits described him.

We have to remember that the desire of the subject is the desire of the Other. The subject is subjected to the signifiers of his own unconscious desire structured by the laws of language. Desire, that Lacan classifies as a term that designates the incompleteness of language and subject, conducts the 
subject to search for the object a, that has been lost. Morales, in an essay titled: Subject: imaginary, symbolic and real says that:

The object $a$ is the cause for the division of the subject, and it comes up in the space language creates beyond physiological need, in the space of demand, that cannot be suppressed by the object of need. It is an object that did not exist before being lost: it is the act of losing it that creates it. ${ }^{3}$ (2008, p. 40).

This is what has happened to Earl Ober: object $a$ is his manhood materialized in his wife. Since his wife is not desirable anymore, he loses his position as a manly subject. Earl Ober has constructed his persona in the discourse of the Other. His ideology and social position is interpellated by the discourse of the Other. We can understand this unconscious functioning of the subject with the words of Morales:

The subject is unavoidably inhabited by an absence, the absence that comes from his own disappearance. However, intimidated, interpellated by the Other, what the subject encounters is the enigma of desire, to which he shall, necessarily, respond. Connected to the structure of the chain of signifiers, we can find the desire of the Other. In the absence of the Other's discourse, for the subject, the enigma of desire dwells. In face of the intimidation caused by the Other, the subject responds to it with what it constitutes at a first moment, which is, absence. This is what the space of the subject and the space of the Other have in common. This is why the desire of the subject should be thought as the desire of the Other. ${ }^{4}(2008$, p. 40).

So, Earl Ober convinces his wife to start a diet. They make plans together and try to figure out the best type of diet to suit Doreen. In this passage, Raymond Carver, using his masterly writing apparatus, portrays in a simple, and even funny moment, the social status, the personality and the educational background of the couple.

They talked about diets. They talked about the protein diets, the vegetable-only diets, the grapefruit-juice diets. But they decided they didn't have the money to buy steaks the protein diet called for. And Doreen said she didn't care for all that many vegetables. And since she didn't like grapefruit juice that much, she didn't see how she could do that one, either.

"Okay, forget it," he said.

"No, you're right," she said. "I'll do something."

"What about exercises?" he said.

"I'm getting all the exercise I need down there," she said.

“Just quit eating," Earl said. "For a few days, anyway." (CARVER, 1976, p. 25).

The Obers could not afford to have steaks, since they did not have the money. Their social position in that moment is clear: they don't have any money. But Carver goes further, when the discourse analyst approaches a statement that reads: "Doreen said she didn't care for all that many vegetables." We should ask ourselves, as discourse analysts: Who is the subject of this sentence? What type of ideology is being materialized in the form of discourse? What kind of conflict exists between the two or more discursive formations in question? This analyst, understanding that there are different readings of the same enunciation, could read the sentence as a portrait of a social class which does not have a healthy

\footnotetext{
${ }^{3}$ Original: "O objeto a é a causa da divisão do sujeito. Surge no espaço que a linguagem cria para além da necessidade fisiológica, no espaço da demanda, que não pode ser suprimida pelo objeto da necessidade. É um objeto que não existia antes de ser perdido: é a perda que o cria."

${ }^{4}$ Original: "Um sujeito irremediavelmente habitado por uma falta, a falta advinda de seu próprio desaparecimento. Entretanto, intimidado, interpelado pelo Outro, o que o sujeito encontra é o enigma do desejo, ao qual deverá necessariamente responder. Ligado à própria estrutura da cadeia de significantes, encontra-se o desejo do Outro. Nas faltas do discurso do Outro, para o sujeito, se aloja o enigma do desejo. Ante a intimidação que lhe faz o Outro, responde com aquilo que se constitui no primeiro tempo, vale dizer, a falta. Isto é o que há de comum entre o campo do sujeito e o campo do Outro. Por isso, o desejo do sujeito deve ser pensado enquanto desejo do Outro."
} 
diet, not only because of money issues, but also because of the educational level it is inscribed in. This situation can be seen when Doreen says she "didn't care" for vegetables. She has a position towards the subject. She inscribes herself in a discursive formation at the moment the evidences of historicity are materialized in discourse. We could infer that, by not enjoying vegetables that much, Doreen's diet represents the diet of most middle-class and lower-class individuals, since she did not eat either meat or vegetables that often, but probably, cheap frozen food and canned food. In the end they decided that the best thing to do was for Doreen to quit eating, that is, starve for a while. There is a pathetic and desperate tone to this. When Earl asks her about exercise, she answers that she is getting enough exercise at her job. This clarifies the idea that Doreen does not have an intellectual challenge at her job and routine, she is always on the move, carrying coffeepots, serving people, etc.

After the conversation Earl becomes obsessed and compulsive about his wife's diet. He controls everything on the diet. He buys a bathroom scale and takes notes of her progress continuously. Doreen starves for weeks and loses many pounds, so many that her co-workers do not think she is feeling well.

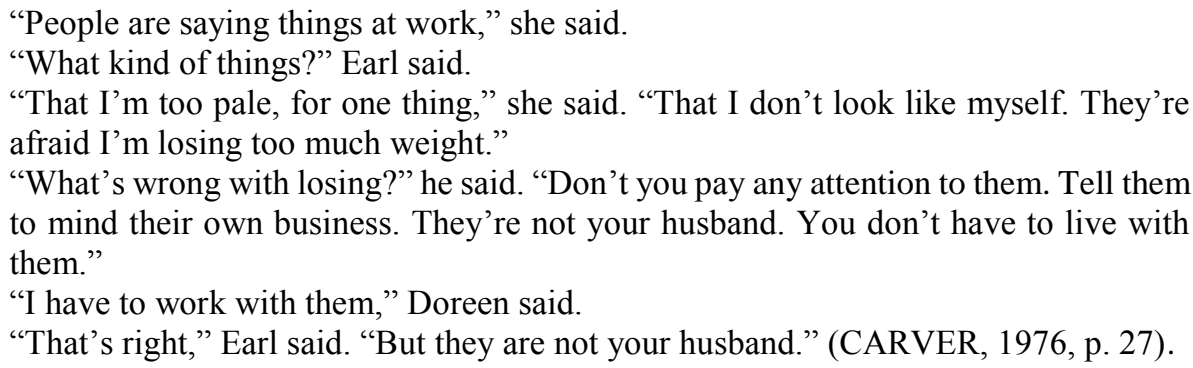

When Doreen says that people are saying things at work, Earl become interested, probably because he was expecting to hear that Doreen's co-workers were commenting on how thin and sexy and desirable she is. Earl spends a lot of time and energy controlling his wife's weight, he is expecting things to come back to "normality". Earl's response manifests that it is not his wife whom he desires. Earl's desire is to have his desires authenticated by the desire of others. Something ambiguous takes place in this passage: Doreen's co-workers are worried about her. Is she really too pale? Sick? Has Doreen become really skinny? Anorexic? Or are they not able to recognize her as herself? They do not accept her with a new body, meaning that she cannot transit to another discursive formation. It is very significant to see that her co-workers said that she didn't look like herself. What can this mean? Nonetheless, the most illustrative moment in this conversation is the passage where Earl asks: "What's wrong with losing?" This is a question most characters in the fictional universe of Carver might ask themselves. The core of this sentence lays in losing. Maybe, losing is the most recurrent image in Carver's stories. The characters are always losing weight, losing respect, losing prestige, losing money, losing their cars, their homes, their families. Earl, in a pathetic attempt to control his wife says that she should not listen to what those people had to say, because they were not her husband. Probably this means that, as a husband, Earl possesses the power and the authority to control his wife, and he continues saying that other people do not have to live with her. However, Doreen simply answers: "I have to work with them." The answer Doreen gives her husband could be simply read as a statement where she makes the type of relation she has with these people explicit, but, in the light of discourse analysis, we should look for evidence that indicates a conflict of classes. According to this approach, we could say that Doreen was saying that she had a position that her husband did not have. "I have to work with them" may silence the fact that Earl does not work, so he should not or could not say anything about the subject. Doreen is defying her husband and the phalo-centric order presented in the universe she inhabits, simply by creating a space where silence reverberates, creating a movement of resistance to the dominant order. 
Earl understands what his wife had done, at least in some level. We can see that when he says "That's right," but still tries to maintain the irrational, controlling, behavioral mumble jumble thoughts when he finishes the sentence with "But they're not your husband."

Towards the end of the story, Earl comes back to the coffee shop, and the situation where his wife is been judged as an object of desires is repeated. But this time, it is Earl who is commenting and asking the opinion of another man in concern to the new re-formed body of his wife. Earl finds himself playing a similar but even more disgusting part than the men at the beginning of the story, making a voyeuristic spectacle of his own wife.

\footnotetext{
"What do you think of that?" Earl said to the man, nodding at Doreen as she moved down the counter. "Don't you think that's something special?"

"The man looked up. He looked at Doreen and then at Earl, and then went back to his newspaper [...]

The other waitress came straight to Doreen. "Who is this character?" she said.

"Who?" Doreen said and looked around with the ice-cream dish in her hand.

"Him." The other waitress said and nodded at Earl. "Who is this joker, anyway?"

Earl put on his best smile. He held it. He held it until he felt his face pulling out of shape.

But the other waitress just studied him, and Doreen began to shake her head slowly. The man had put some change beside his cup and stood up, but he too waited to hear the answer. They all stared at Earl.

"He's a salesman. He's my husband." Doreen said at last, shrugging (CARVER, 1976, p. 29-30).
}

Earl did not have any straight answer from the man who was reading the newspaper. The reader has the impression that the man is quite upset with the situation and the tone of the conversation. Actually, the man never exchanged a single word with Earl. At the end of the situation, the man gives a look to the other waitress that, then, understands what is going on and approaches Doreen. At this moment we have a repetition of the adjective the two businessmen used in the beginning of the story to describe the kind of man who suited Doreen. The other waitress asks Doreen: "Who is that joker?" again we have the confirmation that others see Earl as a loser (joker). But what is really interesting is not the question, but the answer Doreen gives, she says: "He's a salesman. He is my husband." In fact, Earl is acting like a salesman when he tries to establish the value of the merchandise (his wife) by attempting to convince the man with the newspaper to "buy the product". But this analysis could go further, since Doreen's discourse is ambivalent. On the one hand, Doreen identifies Earl as her husband, establishing their kind of relationship in a social category. But on the other hand, Doreen attributes a profession to her unemployed husband maybe trying to restore him to a minimal sense of dignity in that pitiful situation, or, out for pure shame since she then recognizes him as a loser.

\section{CARVING SILENCE}

After an extensive reading and analysis on Raymond Carver's stories, the discourse analyst is able to conclude that silence is a spectrum that involves every aspect of Carver's fictional world. Silence operates in different ways: It appears unquestionably untranslatable in the form of founding silence, the one that is inhabited by all the other meanings that were not filling the enunciation said, the one that carries all the other possible meanings and that is immanent to every enunciation and discourse; Silence also permeates the narratives of Carver in the form of politics of silence, as much as in the panorama of constitutive silence and censorship. Constitutive silence, the one that is invisibly present in every saying, that says " $x$ " for the impossibility of saying " $y$ " is a mechanism of discourse abundantly used by Carver 
that generates ambiguity and polysemy. The elliptical style present in Carver's writing produces silence. It is an elliptical writing method that opens space for ambiguity and that demands the reader to position himself as a subject in a determined discursive formation, and insert meaning into the spaces permeated by silence. Another form of silence in Raymond Carver is the recently discovery that his most celebrated collection of stories, and also the most minimalist one, What we talk about when we talk about love (1981) was dramatically edited to one third of its original length by the famous American editor Gordon Lish. This is an unique example in literature, for a discourse analyst understand the functioning of censorship, the inevitably creation of silenced spaces, and the ideological forces operating in the fields of class and meaning; In a second moment of his career, called the Good Raymond days, Carver developed longer stories. This stories were still focused on discourse and silence, but they deviated themselves from the pessimistic atmosphere that surrounded the first shorter stories. The narratives included in Fires (1983), Cathedral (1983) and Where i'm calling from (1988) did not have the pessimistic aura present within Carver's two first collections of stories Will you please be quiet, please (1976) and What we talk about when we talk about love (1981). These longer narratives, although still portraying characters that represent the same type of discursive formation his older stories used to do, allow the possibility for redemption and salvation. In many stories of these new collections, characters take advantage of the opportunity that is presented to them, and, differently from the older stories where characters did not feel capable of solving things, in the most recent ones, they try solving their problems, usually through discourse and communication, something that was usually denied to them in the older stories.

\section{REFERENCES}

CARVER, Raymond. Will you please be quiet, please? New York: Vintage Books, 1976.

What we talk about when we talk about love. New York: Vintage Books, 1981.

Fires. New York: Vintage Books, 1983.

CORNWELL, Gareth. Mediated Desire and American Dissapointment in the Stories of Raymond Carver. In: Critique: Studies in Contemporary Fiction. 46.4, 2005, p.344-368.

MORALES, B. S. V. Sujeito; imaginário e real. In: MITTMANN, S.; GRIGOLETTO, E.; CAZARIN, E. A. Práticas discursivas e identitárias: sujeito e língua. Porto Alegre: Nova Prova, 2008, p. 34-46.

NESSET, Kirk. This word love: Sexual politics and silence in early Raymond Carver. In: American Literature, v.63, n.2, jun. 1991, Duke University Press, p.292-313.

ORLANDI, Eni P. Análise do Discurso: princípios e procedimentos. Campinas: Pontes, 2000.

P. As formas do silêncio. Campinas: Editora da Unicamp, 2007. 